\title{
An InDel-based linkage map of hot pepper (Capsicum annuum)
}

\author{
Weipeng $\mathrm{Li} \cdot$ Jiaowen Cheng $\cdot$ Zhiming Wu $\cdot$ \\ Cheng Qin · Shu Tan · Xin Tang • Junjie Cui • \\ Li Zhang $\cdot$ Kailin Hu
}

Received: 20 June 2014/Accepted: 27 November 2014/Published online: 21 January 2015

(C) The Author(s) 2015. This article is published with open access at Springerlink.com

\begin{abstract}
Two independent pepper (Capsicum annuиm) genomes were published recently, opening a new era of molecular genetics research on pepper. However, pepper molecular marker technologies are still mainly focusing on the simple sequence repeats derived from public database or genomic library. The development and application of the third generation marker system such as single nucleotide polymorphisms, structure variations as well as insertion/ deletion polymorphisms (InDels) is still in its infancy.
\end{abstract}

Weipeng Li and Jiaowen Cheng have contributed equally to this work.

Electronic supplementary material The online version of this article (doi:10.1007/s11032-015-0219-3) contains supplementary material, which is available to authorized users.

W. Li · J. Cheng $\cdot$ C. Qin $\cdot$ S. Tan $\cdot$ X. Tang $\cdot$

J. Cui $\cdot$ L. Zhang $\cdot$ K. Hu ( $₫)$

College of Horticulture, South China Agricultural

University, Wushan Road 483,

Guangzhou 510642, Guangdong, China

e-mail: hukailin@scau.edu.cn

W. Li

e-mail: liweipeng875@163.com

J. Cheng

e-mail: jiaolong1015@126.com

C. Qin

e-mail: qincheng1001@163.com

S. Tan

e-mail: tsh731t@163.com
In the present study, we developed InDel markers for pepper genetic mapping with the convenience of two whole-genome re-sequenced inbred lines BA3 $(C$. annuиm) and B702 (C. апnиum). A total of 154,519 and 149,755 InDel (1-5 bp) sites were identified for BA3 and B702, respectively, by the alignment of resequencing reads to Zunla-1 reference genome. Then, 14,498 InDel sites (only 4 and $5 \mathrm{bp}$ ) that are different between BA3 and B702 were predicted. Finally, within a random set of 1,000 primer pairs, $251 \mathrm{InDel}$ markers were validated and mapped onto a linkage map using $\mathrm{F}_{2}$ population derived from the intraspecific cross BA3 $\times$ B702. The first InDel-based map, named as BB-InDel map, consisted of 12 linkage groups, covered a genetic distance of $1,178.01 \mathrm{cM}$ and the average distance between bin markers was $5.01 \mathrm{cM}$. Compared to the Zunla-1 reference physical map, high

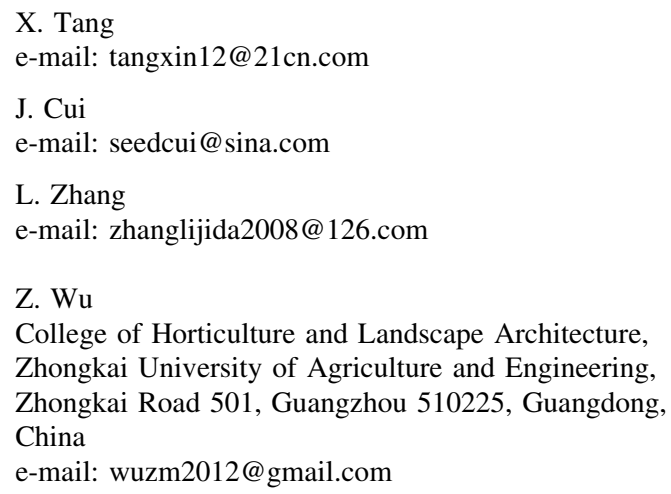


consistency was observed on all 12 chromosomes, and the total length of scaffold anchored and physical distance covered by this map was 299.66 and 2,558.68 Mb, respectively, which accounted for 8.95 and $76.38 \%$ of the Zunla-1 reference genome $(3.35 \mathrm{~Gb})$, respectively. Furthermore, 37 scaffolds (total length of $36.21 \mathrm{Mb}$ ) from the pseudo-chromosome (P0) of the current genome assembly were newly assigned to the corresponding chromosomes by 40 InDel markers. Thus, this map provided good genome coverage and would be useful for basic and applied research in pepper.

Keywords Capsicum annuиm $\cdot \mathrm{InDel} \cdot$ Genetic map · Pepper genome

\section{Introduction}

The genus of Capsicum, which is native to South and Central America (Walsh and Hoot 2001), belongs to the Solanaceae family and includes over 30 species (Moscone et al. 2007). Of these, five are domesticated ones, namely $C$. апnиum, $C$. chinense Jacq., $C$. baccatum, C. pubescens Ruiz \& Pavon and C. frutescens (Pickersgill 1997). Due to their characteristic pungency, flavor and nutrient elements, Capsicum is cultivated all over the world and becomes one of the most economically important vegetable crops with versatile application for food, spice, ornament, medicine, etc. (Qin et al. 2014). Of the five domesticated species, C. апnиum is the main cultivated species in China, which is the largest producer and consumer of pepper (www.fao.org). C. апnиum germplasms have enormous morphological diversity for traits with different fruit size, shape and color (Oyama et al. 2006). Nevertheless, morphological identification can often be problematic when the number of useful traits is limited, which restricts the efficient assessment and utilization of Capsicum genetic resources.

\section{Qin}

Pepper Institute, Zunyi Academy of Agricultural

Sciences, Zunyi 563102, Guizhou, China

C. Qin

Maize Research Institute of Sichuan Agricultural University/Key Laboratory of Biology and Genetic Improvement of Maize in Southwest Region, Ministry of Agriculture, Chengdu 611130, Sichuan, China
Instead, compared to the traditional recognition systems, the DNA marker technology provides a highly reliable tool for rapid and accurate identification of plant species (Jones et al. 2009), which opens a window for us to concern directly on the variations at genomic level, and is now routinely used for study on biodiversity, gene tagging, genetic mapping and marker-assisted selection in various animal and plant systems (Davey et al. 2011; Peleman and van der Voort 2003; Vignal et al. 2002; Sachidanandam et al. 2001). In the last decades, the DNA marker technology of Capsicum also experienced the same developmental process of three generations as the other model organisms. Briefly, based on the tomato- and pepperderived probes, restriction fragment length polymorphism markers (RFLPs) were firstly applied to genetic mapping (Tanksley et al. 1988; Prince et al. 1993) and diversity analysis (Prince et al. 1992; Lefebvre et al. 1993) in Capsicum. It was then replaced by PCRbased marker such as amplified fragment length polymorphism (AFLPs) (Paran et al. 1998), random amplified polymorphic DNA (RAPDs) (Rodriguez et al. 1999), simple sequence repeats (SSRs) (Huang et al. 2001; Yi et al. 2006; Lee et al. 2004) and their derived types (Min et al. 2008; Ince et al. 2010; Wu et al. 2009; Du et al. 2006). In recent years, single nucleotide polymorphism markers (SNPs), being known as one of the third generation marker systems, were also started to be used in pepper by different groups (Jung et al. 2010; Jeong et al. 2010; Qin et al. 2014; Kim et al. 2014; Hill et al. 2013).

As one of the most important downstream application of DNA marker, genetic map is also a basic tool necessarily for QTL analysis and marker-assisted selection (MAS) in breeding. In Capsicum, genetic maps (Qin et al. 2014; Park et al. 2014; Kim et al. 2014; Sugita et al. 2013; Mimura et al. 2012; Lu et al. 2012b; Wu et al. 2009; Barchi et al. 2007; Yi et al. 2006; Minamiyama et al. 2006; Sugita et al. 2005; Paran et al. 2004; Kang et al. 2001; Livingstone et al. 1999; Tanksley et al. 1988) based on intraspecific or interspecific populations were constructed using various marker systems mentioned above. Even though the SNP brought the density of pepper map to an unprecedented height (Qin et al. 2014; Kim et al. 2014), the total number of PCR-based anchored marker is still limited (Sugita et al. 2013).

Insertion/deletion (InDel) polymorphisms, which were based on sequence alignment, were relatively 
abundant and uniformly distributed throughout the genome (Mills et al. 2006; Pacurar et al. 2012; Liu et al. 2013). For a species with a reference genome, whole-genome re-sequencing (WDR) can permit the mining of genome data for a large number of genomewide markers such as SNPs, structure variation (SVs) as well as InDels (Xie et al. 2010; McNally et al. 2009; Qin et al. 2014). With the decreasing cost of next generation sequencing (NGS), the InDels, as a kind of conventional marker to breeder, have been one of the most frequently used markers nowadays (Lv et al. 2013; Liu et al. 2012, 2013; Vasemagi et al. 2010; Ollitrault et al. 2012). So it would be an excellent complement of anchor marker for pepper since the genome sequence was published by two independent groups (Qin et al. 2014; Kim et al. 2014). Nevertheless, to our knowledge, with the exception of a very limited set being identified in silico by comparative transcriptomics (Lu et al. 2011, 2012a), InDel markers have barely been applied to molecular genetics of Capsicum practically, such as genetic mapping up to now.

Here, we present the mining of InDels between two C. annuum lines BA3 and B702, both of which were already re-sequenced in depth of 28.59- and 30.30fold, respectively. An InDel-based linkage map of pepper was then constructed using the intraspecific $\mathrm{F}_{2}$ population derived from the cross BA3 $\times$ B072. The genetic map was then compared with its physical map by anchoring onto the Zunla-1 reference genome. The first InDel map of pepper would be useful for basic and applied research in commercially important cultivated C. аппиит.

\section{Materials and methods}

Plant materials and DNA extraction

The $\mathrm{F}_{2}$ genetic mapping population consisting of over 300 progenies was derived from the intraspecific cross between two pure lines of $C$. апnиит (BA3 $\times$ B702) (Qin et al. 2014). In the present study, a random subset of 178 individuals was selected for mapping with InDels. The $F_{2}$ progenies and parental lines were grown in the open field in Zengcheng, Guangzhou City, China. Young leaves were collected for genomic DNA isolation using the CTAB method (Murray and Thompson 1980).
InDel development and frequency calculation

InDel sites were identified by aligning BA3 and B702 re-sequencing reads to the initial Zunla-1 scaffold genome with SOAPindel (http://soap.genomics.org. $\mathrm{cn} /$ ), according to the previous study (Qin et al. 2014). To increase the selection efficiency of polymorphic primers, a subset of InDels (only 4 and $5 \mathrm{bp}$ ) between BA3 and B702 was predicted by a customized bioinformatic analysis pipeline. Primer3 software (Untergasser et al. 2012) was then used to search primers for each InDel site according to the following parameters settings: (1) predicted product size is between 100 and $300 \mathrm{bp}$, (2) $5^{\prime}$ and $3^{\prime}$ end mismatch $<3$ and $<1$, respectively, and (3) only primers with one hit in the genome assembly were retained. With the accomplishment of chromosome building of reference genome, the retained primers were then anchored onto the final twelve chromosomes (P1-P12) and one pseudochromosome (P0) by BLAST (Altschul et al. 1997). InDel frequency was calculated by the formula: (number of heterozygote $\times 1+$ number of homozygote $\times 2) / 2 N, N=$ total number of accessions.

PCR amplification and marker scoring

Polymorphic markers that were unique to either of the parental lines and present in the $\mathrm{F}_{1}$ population were used for genetic mapping. PCR mixture contained $10 \mathrm{ng}$ genomic DNA, $100 \mu \mathrm{M}$ of each dNTP, $1.5 \mu \mathrm{M}$ of each primer, $1 \times$ reaction buffer (including $\mathrm{Mg}^{2+}$ ) and 0.5 unit of Taq polymerase (Dsbio) in a final volume of $20 \mu \mathrm{L}$. The reaction was performed as follows: an initial $5 \mathrm{~min}$ at $94{ }^{\circ} \mathrm{C} ; 35$ cycles of $45 \mathrm{~s}$ at $94{ }^{\circ} \mathrm{C}, 45 \mathrm{~s}$ at $55-58{ }^{\circ} \mathrm{C}$, and $2 \mathrm{~min}$ at $72{ }^{\circ} \mathrm{C}$, and a final $10 \mathrm{~min}$ at $72{ }^{\circ} \mathrm{C}$. Subsequently, $2-4 \mu \mathrm{L}$ of the PCR product was used for electrophoresis in $6 \%$ polyacrylamide gel.

Linkage map construction and comparison with physical map

Linkage analysis was performed using JoinMap 4.0 software (Van Ooijen 2006). Since the physical mapping information on the polymorphic markers was available, groups were firstly created with the command "Create Groups Using a Map Node," the remaining unmapped (actually anchored onto the P0) markers were assigned to the known groups with the Strongest Cross Link information. Regression algorithm was used 
for mapping on each group. Recombination values were converted to genetic distances using the Kosambi mapping function. The genetic map and physical map were drawn using Mapchart 2.2 software (Voorrips 2002). Markers with segregation ratios that differed from expected ratio were classified as segregation distortion markers. A region with five or more adjacent skewed segregation marker was defined as a segregation distortion region (SDR).

\section{Results and discussion}

Development of the InDel markers

Re-sequencing could help us to discover genome-wide variations on a large scale and provide excellent resources to the plant science community (Albert and Chang 2014). With the ongoing of pepper genome project, we re-sequenced a total of more than 20 different cultivated varieties including the parental lines BA3 and B702 used in the present study (Qin et al. 2014). Based on the alignment of the sequencing reads corresponding to 28.59- (for BA3) and 30.30 (for B702)-fold depth to the reference, 154,519 and $149,755$ small InDels ( $1-5 \mathrm{bp})$ were identified in BA3 and B702, respectively. Through comparative analysis by a customized bioinformatic analysis pipeline, 14,498 InDels (only 4 and $5 \mathrm{bp}$ ) were identified between BA3 and B702 and used for searching primers. Finally, according to the requirements of primer design, a total of 2,324 (16.03\%) primer pairs were successfully obtained. To evaluate their potential value in practice, a random subset of 1,000 primer pairs were chosen to screen polymorphism between BA3 and B702 and 922 (92.2\%) were amplified specifically, indicating the high quality of the reference genome. Two hundred and seventy-two (27.2\%) polymorphic markers were validated, and the majority of the polymorphic markers $(>96 \%)$ are codominant inheritance. As expected, the polymorphic rate became lower $(13.1 \%)$ when used to test in another pair of parental lines, BA3 and YNXML ( $C$. frutescens) in our laboratory (unpublished data).

\section{Construction of the InDel map}

The $\mathrm{F}_{2}$ population consisting of 178 progenies derived from the cross BA3 $\times$ B702 was genotyped with the
Fig. 1 InDel-based linkage map of pepper (C. annuum) and comparison with its physical map. All InDel markers start with a prefix 'CIDH'. Markers written with red color are anchored onto the pseudo-chromosome (P0) of the BB-SNP map-based reference genome assembly. A total of 31 distorted segregation markers mapped on this map are underlined and italic. (Color figure online)

above InDel markers with very less missing rate $(<1.7 \%)$. An intraspecific linkage map of C. апnиum, designated as the BB-InDel map, was built with 251 InDel markers (236 genetic bins), and the remaining 21 markers could not be integrated because of insufficient linkage (Fig. 1). This is the first report on the construction of intraspecific linkage map purely based on InDel markers for pepper. In order to evaluate the transferability of InDel markers among $C$. аппиит accessions, InDel frequency was calculated using the re-sequencing data from a set of $C$. аппиит accessions. The mean frequency of 251 mapped InDels markers among the 17 C. апnиum accessions was $20.07 \%$ (Fig. 2), indicating that the BB-InDel map can be used for basic and applied research in the future.

The map consisted of 12 linkage groups (LGs) covering a total genetic distance of $1,178.01 \mathrm{cM}$ with an average density of one bin marker for every $5.01 \mathrm{cM}$ (Table 1; Fig. 1). The maximum genetic distance between two bin markers was $42.44 \mathrm{cM}$, and the number of mapped markers on LGs ranged from 8 (LG5) to 28 (LG3). Segregation distortion (SD) occurs when the segregation ratio deviates from the expected Mendelian ratio (Kuittinen et al. 2004). Here, 35 out of $272(12.9 \%)$ markers showed distorted segregation, which is lower than that of interspecific population (Kang et al. 2001; Livingstone et al. 1999) but is similar to the intraspecific crossing (Barchi et al. 2007; Sugita et al. 2005; Lefebvre et al. 2002). Two segregation distortion regions (SDRs) were detected on LG5 and LG12, respectively $(P<0.05)$. All marker alleles within the SDR in LG5 were associated with the male line B702, and the other SDR in LG12 were skewed toward the hybrid of the parental lines. The phenomenon might be resulted from some so-called segregation distorted factors (Lyttle 1991), which could alter the recombination frequency in these regions.

Genetic and physical map comparison

Initially, the discovery of InDels was based on the alignment of re-sequencing reads to the Zunla-1 scaffold 


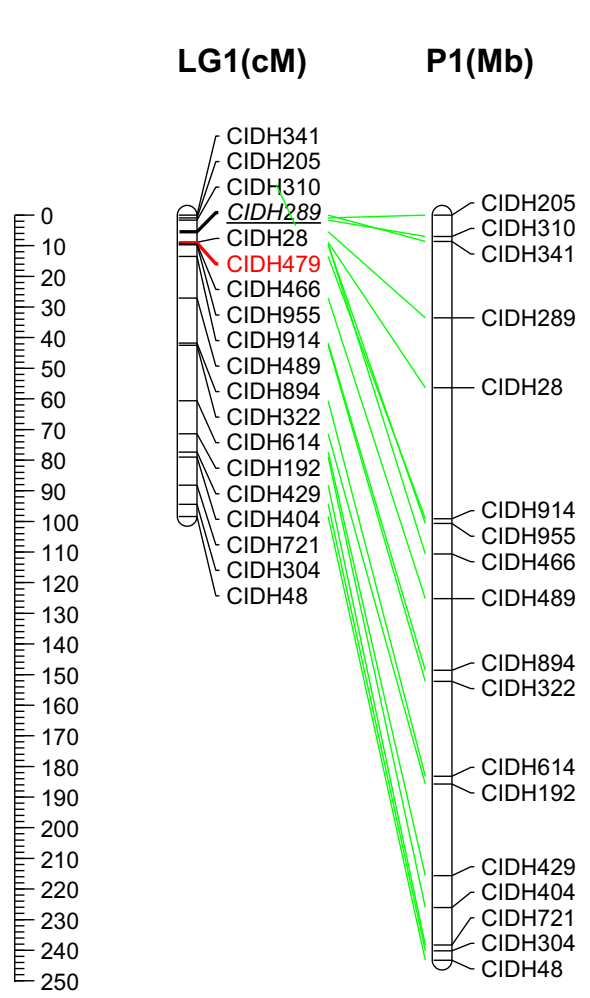

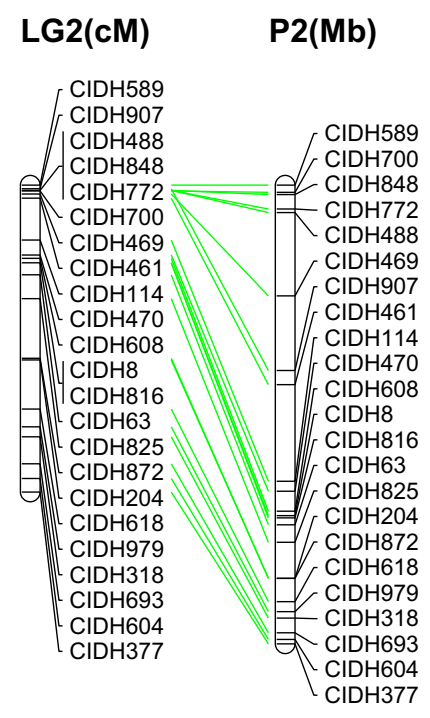

\section{LG3(cM)}

P3(Mb)

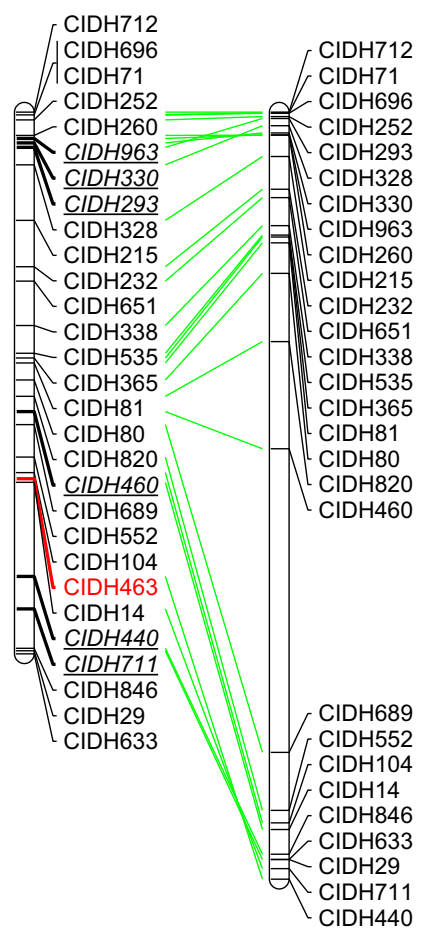

\section{LG4(cM) P4(Mb)}

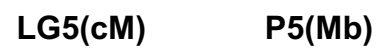

LG6(cM)

P6(Mb)
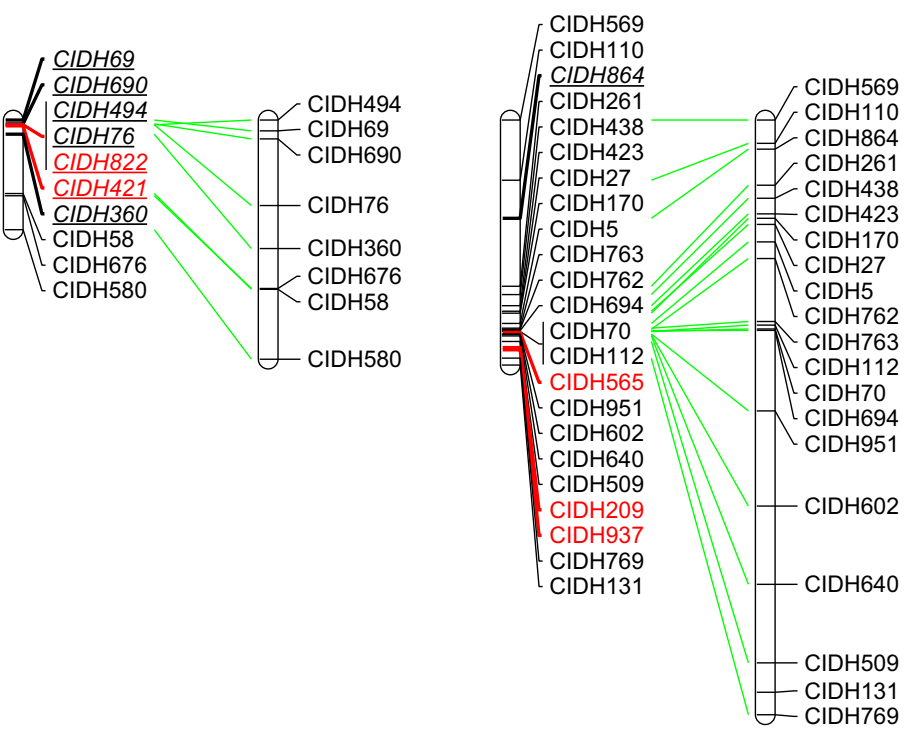


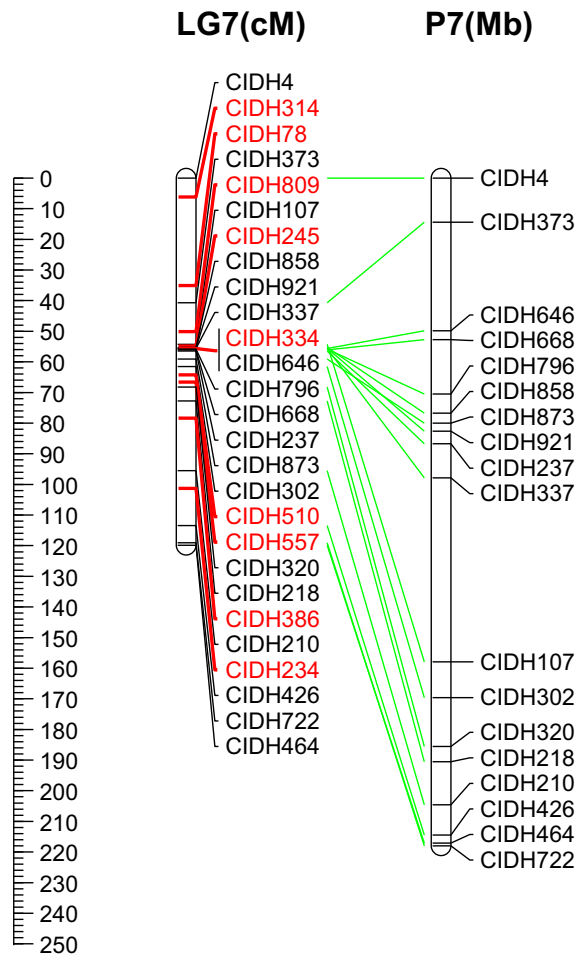

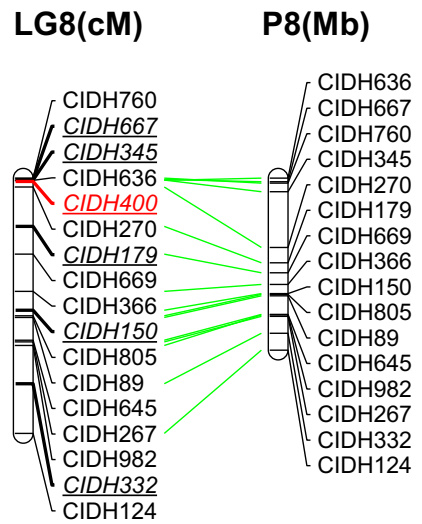

LG9(cM)

$\mathrm{P} 9(\mathrm{Mb})$

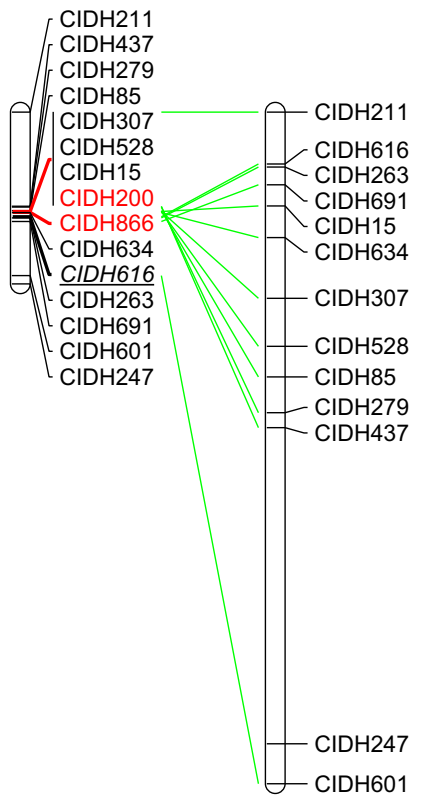

\section{LG10(cM) P10(Mb)}

\section{LG11(cM) P11(Mb)}

LG12(cM)

P12(Mb)
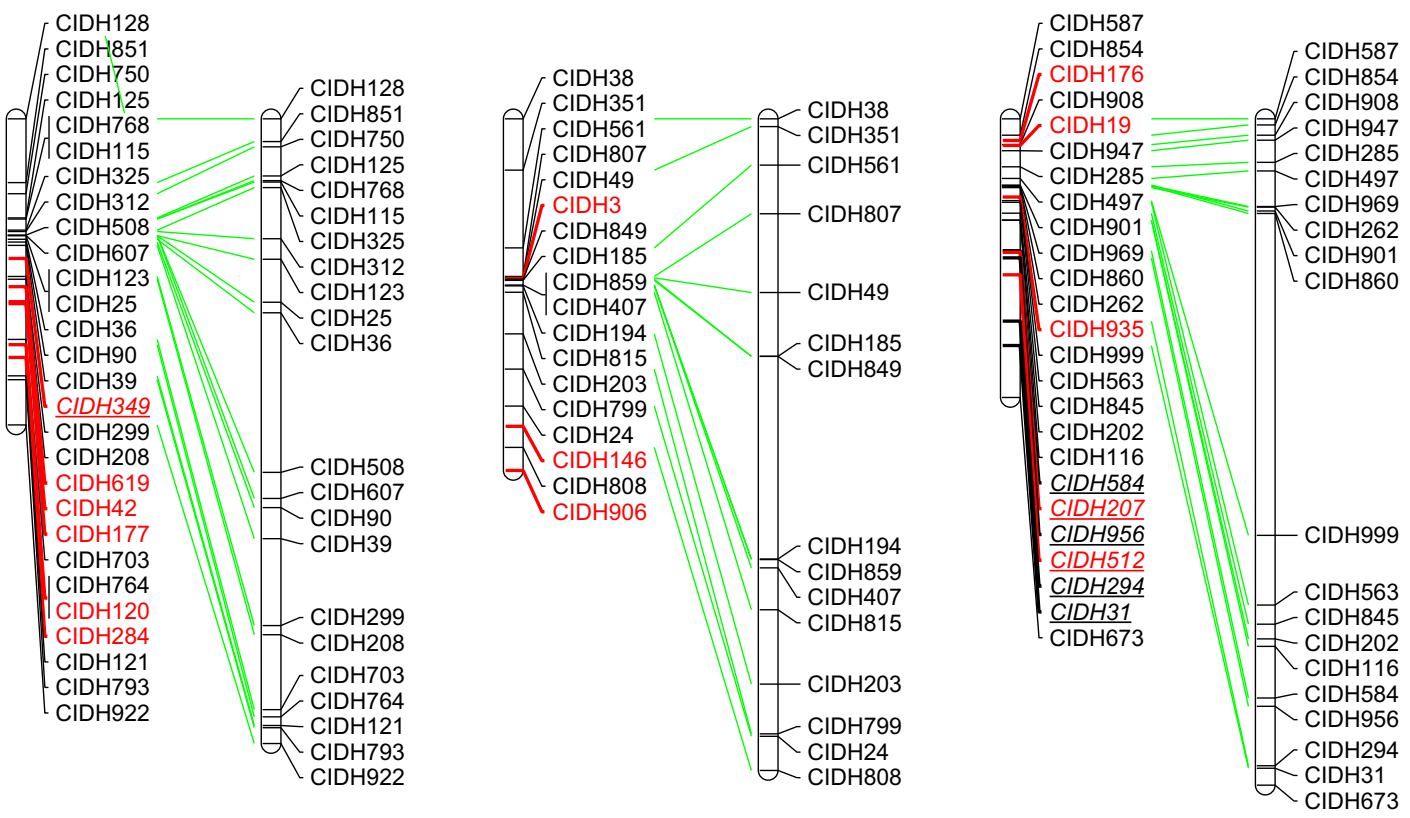

Fig. 1 continued 


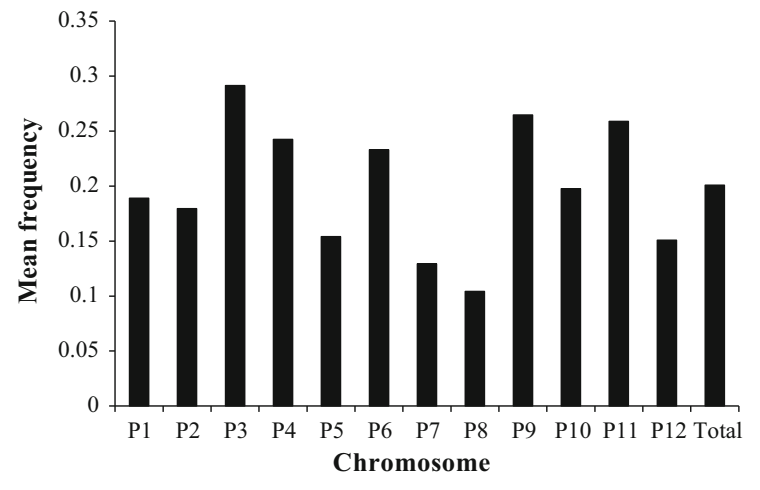

Fig. 2 Mean frequency of 251 markers mapped on the BBInDel map among 17 re-sequenced $C$. апnиum accessions

genome. With the accomplishment of chromosome building of the Zunla-1 reference genome (http:// peppersequence.genomics.cn) and the coordinate conversion of scaffold to that of chromosome, the 12 LGs were successfully assigned to the corresponding 12 chromosomes (P1-P12) based on the 211 anchored markers (Table 1 and S1, Fig. 1). The remaining 40 markers are mapped onto the pseudo-chromosome (P0) according to the current assembly of reference genome. They scattered on 37 different scaffolds, spanning a total length of $36.21 \mathrm{Mb}$ (Table 1 and S1). Because the Zunla-1 chromosome building is based on the BB-SNP map (Qin et al. 2014), which is developed using the same F2 population derived from the cross BA3 $\times$ B702, the 37 scaffolds would be suggestibly assembled into the corresponding chromosomes (P1P12) based on this InDel linkage map, providing a reference of genome improvement in some degree.

According to the comparative analysis, we found that the consistency between the genetic and physical position on all 12 chromosomes was high (Fig. 1). The total length of scaffold anchored and physical distance covered by this map is 299.66 and $2,558.68 \mathrm{Mb}$, respectively (Table 1), which accounted for 8.95 and $76.38 \%$ of the Zunla-1 reference genome $(3.35 \mathrm{~Gb})$, respectively. However, there were still some inconsistent orders within certain a very limited region, which was possibly caused by the different mapping algorithm or putative homology-based scaffold orientation (Qin et al. 2014). Nevertheless, clustering of markers around the putative centromeric regions was evidently observed on several chromosomes such as P3, P4, P6, P10-P12 (Fig. 1). On the other hand, plots of genetic versus physical distance also permitted us to observe $\mathrm{S}$ shape on all chromosomes with exception of P1, P2, P5 and P8 (Fig. S1). This is seemly normal for $\mathrm{P} 2$ and $\mathrm{P} 8$ because they are acrocentric chromosomes in C. апnиum (Lanteri and Pickersgill 1993). In terms

Table 1 Statistics of the pepper InDel-based linkage map and improvement for current assembly of Zunla-1 genome

\begin{tabular}{|c|c|c|c|c|c|c|c|c|c|c|c|}
\hline \multirow{2}{*}{$\begin{array}{l}\text { LG (chromo } \\
\text { some) }\end{array}$} & \multicolumn{2}{|l|}{ Mapped } & \multicolumn{3}{|c|}{ Bin distance $(\mathrm{cM})$} & \multicolumn{3}{|c|}{ Map length } & \multicolumn{3}{|c|}{ Improvement for assembly } \\
\hline & Marker & Bin & Average & Min & $\operatorname{Max}$ & $\begin{array}{l}\text { Genetic } \\
(\mathrm{cM})\end{array}$ & $\begin{array}{l}\text { Anchored } \\
(\mathrm{Mb})^{\mathrm{a}}\end{array}$ & $\begin{array}{l}\text { Physical } \\
(\mathrm{Mb})^{\mathrm{b}}\end{array}$ & Marker $^{\mathrm{c}}$ & Scaffold & $\begin{array}{l}\text { Length } \\
(\mathrm{Mb})\end{array}$ \\
\hline LG1 (P1) & 19 & 19 & 5.47 & 0.16 & 18.09 & 98.41 & 24.81 & 288.89 & 1 & 1 & 0.44 \\
\hline LG2 (P2) & 23 & 20 & 5.28 & 0.18 & 19.53 & 100.24 & 25.99 & 162.43 & 0 & 0 & - \\
\hline LG3 (P3) & 29 & 28 & 6.55 & 0.82 & 30.76 & 176.82 & 28.41 & 253.84 & 1 & 1 & 0.09 \\
\hline LG4 (P4) & 17 & 17 & 7.62 & 0.32 & 42.44 & 121.84 & 23.92 & 205.50 & 7 & 5 & 8.25 \\
\hline LG5 (P5) & 10 & 8 & 5.11 & 0.21 & 19.43 & 35.77 & 13.53 & 200.29 & 2 & 2 & 3.49 \\
\hline LG6 (P6) & 23 & 22 & 3.81 & 0.14 & 22.17 & 79.98 & 30.25 & 206.18 & 3 & 3 & 3.06 \\
\hline LG7 (P7) & 27 & 26 & 4.79 & 0.02 & 28.88 & 119.87 & 32.29 & 221.90 & 9 & 9 & 7.64 \\
\hline LG8 (P8) & 17 & 17 & 5.21 & 0.10 & 16.19 & 83.32 & 17.76 & 152.79 & 1 & 1 & 0.59 \\
\hline LG9 (P9) & 15 & 12 & 5.10 & 0.10 & 30.70 & 56.07 & 14.53 & 226.90 & 2 & 1 & 2.48 \\
\hline LG10 (P10) & 28 & 25 & 4.16 & 0.12 & 20.88 & 99.92 & 40.09 & 205.30 & 6 & 6 & 8.43 \\
\hline LG11 (P11) & 18 & 17 & 7.18 & 0.21 & 25.42 & 114.80 & 21.41 & 205.17 & 3 & 3 & 0.54 \\
\hline LG12 (P12) & 25 & 25 & 3.79 & 0.02 & 16.98 & 90.97 & 26.67 & 229.49 & 5 & 5 & 1.19 \\
\hline Total & 251 & 236 & 5.01 & - & - & $1,178.01$ & 299.66 & $2,558.68$ & 40 & 37 & 36.21 \\
\hline
\end{tabular}

\footnotetext{
a Total length of scaffolds anchored by InDel markers

b Spanned length on current Zunla-1 assembly

c Number of marker that anchored onto the chromosome P0 in the Zunla-1 reference genome
} 
of P1 and P5, the relatively low densities of one marker per $10.84 \mathrm{Mb}$ may be the main reason and the plots provided clear reference for the following map saturation. Therefore, these data showed that the BBInDel map covered nearly the entire genome and could serve as a basic reference map for future genetics and QTL analysis in pepper.

\section{Conclusions}

Re-sequencing technology permitted the mining of over ten thousand small InDels (4 and $5 \mathrm{bp}$ ) between two elite inbred lines of $C$. annuum. As a pilot study on the application of recently published pepper genome, 272 polymorphic InDel markers were validated and a genetic map was constructed with 251 purely InDel markers. Comparison between the genetic and physical map indicated the good genome coverage of the map. Therefore, the InDel markers and map present here provided a collection of publicly available anchor markers and will be useful for genetic/QTL analysis in pepper.

Acknowledgments This work was supported by the Guangdong Natural Science Foundation of China (S2011030001410), the National High Technology Research and Development Program ("863" Program) of China (2012AA100103), the National Natural Science Foundation of China (31372076, 31201639), and Zunyi City and Zunyi Academy of Agricultural Sciences Natural Science Foundation of China Grant (201201).

Open Access This article is distributed under the terms of the Creative Commons Attribution License which permits any use, distribution, and reproduction in any medium, provided the original author(s) and the source are credited.

\section{References}

Albert VA, Chang TH (2014) Evolution of a hot genome. Proc Natl Acad Sci USA 111(14):5069-5070. doi:10.1073/pnas. 1402378111

Altschul SF, Madden TL, Schaffer AA, Zhang J, Zhang Z, Miller W, Lipman DJ (1997) Gapped BLAST and PSIBLAST: a new generation of protein database search programs. Nucleic Acids Res 25(17):3389-3402

Barchi L, Bonnet J, Boudet C, Signoret P, Nagy I, Lanteri S, Palloix A, Lefebvre V (2007) A high-resolution, intraspecific linkage map of pepper (Capsicum annuum L.) and selection of reduced recombinant inbred line subsets for fast mapping. Genome 50(1):51-60. doi:10.1139/g06-140
Davey JW, Hohenlohe PA, Etter PD, Boone JQ, Catchen JM, Blaxter ML (2011) Genome-wide genetic marker discovery and genotyping using next-generation sequencing. Nat Rev Genet 12(7):499-510. doi:10.1038/Nrg3012

Du XH, Wang DY, Gong ZH (2006) Development and refinement of a new marker technique-restriction site amplified polymorphism (RSAP). J Northwest A\&F Univ (Nat Sci Ed) 34(9):45-49, 54

Hill TA, Ashrafi H, Reyes-Chin-Wo S, Yao J, Stoffel K, Truco MJ, Kozik A, Michelmore RW, Van Deynze A (2013) Characterization of Capsicum annuum genetic diversity and population structure based on parallel polymorphism discovery with a $30 \mathrm{~K}$ unigene Pepper GeneChip. PLoS One 8(2):e56200. doi:10.1371/journal.pone.0056200

Huang S, Zhang B, Dan M, Linda C, Yang G, Guo J (2001) Development of pepper SSR markers from sequence databases. Euphytica 117(2):163-167. doi:10.1023/a: 1004059722512

Ince A, Karaca M, Naci Onus A (2010) CAPS-microsatellites: use of CAPS method to convert non-polymorphic microsatellites into useful markers. Mol Breed 25(3):491-499. doi:10.1007/s11032-009-9347-y

Jeong HJ, Jo YD, Park SW, Kang BC (2010) Identification of Capsicum species using SNP markers based on high resolution melting analysis. Genome 53(12):1029-1040. doi:10.1139/G10-094

Jones N, Ougham H, Thomas H, Pasakinskiene I (2009) Markers and mapping revisited: finding your gene. New Phytol 183(4):935-966. doi:10.1111/j.1469-8137.2009.02933.x

Jung J-K, Park S-W, Liu WY, Kang B-C (2010) Discovery of single nucleotide polymorphism in Capsicum and SNP markers for cultivar identification. Euphytica 175(1):91-107

Kang BC, Nahm SH, Huh JH, Yoo HS, Yu JW, Lee MH, Kim BD (2001) An interspecific (Capsicum annuum $\times$ C. chinese) $\mathrm{F}_{2}$ linkage map in pepper using RFLP and AFLP markers. Theor Appl Genet 102(4):531-539. doi:10.1007/ s001220051678

Kim S, Park M, Yeom SI, Kim YM, Lee JM, Lee HA, Seo E, Choi J, Cheong K, Kim KT, Jung K, Lee GW, Oh SK, Bae C, Kim SB, Lee HY, Kim SY, Kim MS, Kang BC, Jo YD, Yang HB, Jeong HJ, Kang WH, Kwon JK, Shin C, Lim JY, Park JH, Huh JH, Kim JS, Kim BD, Cohen O, Paran I, Suh MC, Lee SB, Kim YK, Shin Y, Noh SJ, Park J, Seo YS, Kwon SY, Kim HA, Park JM, Kim HJ, Choi SB, Bosland PW, Reeves G, Jo SH, Lee BW, Cho HT, Choi HS, Lee MS, Yu Y, Do Choi Y, Park BS, van Deynze A, Ashrafi H, Hill T, Kim WT, Pai HS, Ahn HK, Yeam I, Giovannoni JJ, Rose JKC, Sorensen I, Lee SJ, Kim RW, Choi IY, Choi BS, Lim JS, Lee YH, Choi D (2014) Genome sequence of the hot pepper provides insights into the evolution of pungency in Capsicum species. Nat Genet 46(3):270. doi:10.1038/ Ng.2877

Kuittinen H, de Haan AA, Vogl C, Oikarinen S, Leppala J, Koch M, Mitchell-Olds T, Langley CH, Savolainen O (2004) Comparing the linkage maps of the close relatives Arabidopsis lyrata and A. thaliana. Genetics 168(3):1575-1584. doi:10.1534/genetics.103.022343

Lanteri S, Pickersgill B (1993) Chromosomal structural changes in Capsicum annuum L. and C. chinense Jacq. Euphytica 67(1-2):155-160. doi:10.1007/bf00022739 
Lee JM, Nahm SH, Kim YM, Kim BD (2004) Characterization and molecular genetic mapping of microsatellite loci in pepper. Theor Appl Genet 108(4):619-627. doi:10.1007/ s00122-003-1467-x

Lefebvre V, Palloix A, Rives M (1993) Nuclear RFLP between pepper cultivars (Capsicum annuum L.). Euphytica 71(3):189-199

Lefebvre V, Pflieger S, Thabuis A, Caranta C, Blattes A, Chauvet JC, Daubèze AM, Palloix A (2002) Towards the saturation of the pepper linkage map by alignment of three intraspecific maps including known-function genes. Genome 45(5):839-854. doi:10.1139/g02-053

Liu P, Cai X-X, Lu B-R (2012) Single-seeded InDel fingerprints in rice: an effective tool for indica-japonica rice classification and evolutionary studies. J Syst Evol 50:1-11

Liu B, Wang Y, Zhai W, Deng J, Wang H, Cui Y, Cheng F, Wang X, Wu J (2013) Development of InDel markers for Brassica rapa based on whole-genome re-sequencing. Theor Appl Genet 126:231-239

Livingstone KD, Lackney VK, Blauth JR, van Wijk R, Jahn MK (1999) Genome mapping in capsicum and the evolution of genome structure in the solanaceae. Genetics 152(3): 1183-1202

Lu FH, Yoon MY, Cho YI, Chung JW, Kim KT, Cho MC, Cheong SR, Park YJ (2011) Transcriptome analysis and SNP/SSR marker information of red pepper variety YCM334 and Taean. Sci Hortic 129(1):38-45. doi:10. 1016/j.scienta.2011.03.003

Lu FH, Cho MC, Park YJ (2012a) Transcriptome profiling and molecular marker discovery in red pepper, Capsicum annuит L. TF68. Mol Biol Rep 39(3):3327-3335. doi:10. 1007/s11033-011-1102-x

Lu FH, Kwon SW, Yoon MY, Kim KT, Cho MC, Yoon MK, Park YJ (2012b) SNP marker integration and QTL analysis of 12 agronomic and morphological traits in $\mathrm{F}_{8}$ RILs of pepper (Capsicum annuum L.). Mol Cells 34(1):25-34. doi:10.1007/s10059-012-0018-1

Lv H-H, Yang L-M, Kang J-G, Wang Q-B, Wang X-W, Fang Z-Y, Liu Y-M, Zhuang M, Zhang Y-Y, Lin Y, Yang Y-H, Xie B-Y, Liu B, Liu J-S (2013) Development of InDel markers linked to Fusarium wilt resistance in cabbage. Mol Breed 32(4):961-967

Lyttle TW (1991) Segregation distorters. Annu Rev Genet 25:511-557. doi:10.1146/annurev.ge.25.120191.002455

McNally KL, Childs KL, Bohnert R, Davidson RM, Zhao K, Ulat VJ, Zeller G, Clark RM, Hoen DR, Bureau TE, Stokowski R, Ballinger DG, Frazer KA, Cox DR, Padhukasahasram B, Bustamante CD, Weigel D, Mackill DJ, Bruskiewich RM, Ratsch G, Buell CR, Leung H, Leach JE (2009) Genomewide SNP variation reveals relationships among landraces and modern varieties of rice. Proc Natl Acad Sci USA 106(30):12273-12278. doi:10.1073/pnas. 0900992106

Mills RE, Luttig CT, Larkins CE, Beauchamp A, Tsui C, Pittard WS, Devine SE (2006) An initial map of insertion and deletion (INDEL) variation in the human genome. Genome Res 16(9):1182-1190. doi:10.1101/gr.4565806

Mimura Y, Inoue T, Minamiyama Y, Kubo N (2012) An SSRbased genetic map of pepper (Capsicum annuиm L.) serves as an anchor for the alignment of major pepper maps. Breed Sci 62(1):93-98
Min WK, Han JH, Kang WH, Lee HR, Kim BD (2008) Reverse random amplified microsatellite polymorphism reveals enhanced polymorphisms in the $3^{\prime}$ end of simple sequence repeats in the pepper genome. Mol Cells 26(3):250-257

Minamiyama Y, Tsuro M, Hirai M (2006) An SSR-based linkage map of Capsicum annuum. Mol Breed 18(2):157-169. doi:10.1007/s11032-006-9024-3

Moscone EA, Scaldaferro MA, Grabiele M, Cecchini NM, Garcia YS, Jarret R, Davina JR, Ducasse DA, Barboza GE, Ehrendorfer F (2007) The evolution of chili peppers (Capsicum-Solanaceae): a cytogenetic perspective. Acta Hortic 745:137-169

Murray MG, Thompson WF (1980) Rapid isolation of high molecular weight plant DNA. Nucleic Acids Res 8(19):4321-4325

Ollitrault F, Terol J, Martin AA, Pina JA, Navarro L, Talon M, Ollitrault P (2012) Development of indel markers from Citrus clementina (Rutaceae) BAC-end sequences and interspecific transferability in Citrus. Am $\mathrm{J}$ Bot 99(7):e268-e273. doi:10.3732/ajb.1100569

Oyama K, Hernandez-Verdugo S, Sanchez C, González-Rodríguez A, Sanchez-Pena P, Garzon-Tiznado JA, Casas A (2006) Genetic structure of wild and domesticated populations of Capsicum annuum (Solanaceae) from northwestern Mexico analyzed by RAPDs. Genet Resour Crop Evol 53(3):553-562

Pacurar DI, Pacurar ML, Street N, Bussell JD, Pop TI, Gutierrez L, Bellini C (2012) A collection of INDEL markers for map-based cloning in seven Arabidopsis accessions. J Exp Bot 63(7):2491-2501. doi:10.1093/jxb/err422

Paran I, Aftergoot E, Shifriss C (1998) Variation in Capsicum annuum revealed by RAPD and AFLP markers. Euphytica 99(3):167-173

Paran I, van der Voort JR, Lefebvre V, Jahn M, Landry L, van Schriek M, Tanyolac B, Caranta C, Chaim AB, Livingstone K, Palloix A, Peleman J (2004) An integrated genetic linkage map of pepper (Capsicum spp.). Mol Breed 13(3):251-261. doi:10.1023/b:molb.0000022526.30914.31

Park S-W, Jung J-K, Choi E-A, Kwon J-K, Kang J-H, Jahn M, Kang B-C (2014) An EST-based linkage map reveals chromosomal translocation in Capsicum. Mol Breed. doi:10.1007/s11032-014-0089-0

Peleman JD, van der Voort JR (2003) Breeding by design. Trends Plant Sci 8(7):330-334. doi:10.1016/S13601385(03)00134-1

Pickersgill B (1997) Genetic resources and breeding of Capsicum spp. Euphytica 96(1):129-133. doi:10.1023/a: 1002913228101

Prince JP, Loaiza-Figueroa F, Tanksley SD (1992) Restriction fragment length polymorphism and genetic distance among Mexican accessions of Capsicum. Genome 35(5):726-732

Prince JP, Pochard E, Tanksley SD (1993) Construction of a molecular linkage map of pepper and a comparison of synteny with tomato. Genome 36(3):404-417. doi:10. $1139 / \mathrm{g} 93-056$

Qin C, Yu C, Shen Y, Fang X, Chen L, Min J, Cheng J, Zhao S, Xu M, Luo Y, Yang Y, Wu Z, Mao L, Wu H, Ling-Hu C, Zhou H, Lin H, Gonzalez-Morales S, Trejo-Saavedra DL, Tian H, Tang X, Zhao M, Huang Z, Zhou A, Yao X, Cui J, Li W, Chen Z, Feng Y, Niu Y, Bi S, Yang X, Li W, Cai H, Luo X, Montes-Hernandez S, Leyva-Gonzalez MA, Xiong 
Z, He X, Bai L, Tan S, Tang X, Liu D, Liu J, Zhang S, Chen M, Zhang L, Zhang L, Zhang Y, Liao W, Zhang Y, Wang M, Lv X, Wen B, Liu H, Luan H, Zhang Y, Yang S, Wang X, Xu J, Li X, Li S, Wang J, Palloix A, Bosland PW, Li Y, Krogh A, Rivera-Bustamante RF, Herrera-Estrella L, Yin Y, Yu J, Hu K, Zhang Z (2014) Whole-genome sequencing of cultivated and wild peppers provides insights into Capsicum domestication and specialization. Proc Natl Acad Sci USA 111(14):5135-5140. doi:10.1073/pnas. 1400975111

Rodriguez JM, Berke T, Engle L, Nienhuis J (1999) Variation among and within Capsicum species revealed by RAPD markers. Theor Appl Genet 99(1-2):147-156. doi:10. 1007/s001220051219

Sachidanandam R, Weissman D, Schmidt SC, Kakol JM, Stein LD, Marth G, Sherry S, Mullikin JC, Mortimore BJ, Willey DL, Hunt SE, Cole CG, Coggill PC, Rice CM, Ning Z, Rogers J, Bentley DR, Kwok PY, Mardis ER, Yeh RT, Schultz B, Cook L, Davenport R, Dante M, Fulton L, Hillier L, Waterston RH, McPherson JD, Gilman B, Schaffner S, Van Etten WJ, Reich D, Higgins J, Daly MJ, Blumenstiel B, Baldwin J, Stange-Thomann N, Zody MC, Linton L, Lander ES, Altshuler D (2001) A map of human genome sequence variation containing 1.42 million single nucleotide polymorphisms. Nature 409(6822):928-933. doi: $10.1038 / 35057149$

Sugita T, Kinoshita T, Kawano T, Yuji K, Yamaguchi K, Nagata R, Shimizu A, Chen L, Kawasaki S, Todoroki A (2005) Rapid construction of a linkage map using high-efficiency genome scanning/AFLP and RAPD, based on an intraspecific, doubled-haploid population of Capsicum annuum. Breed Sci 55(3):287-295

Sugita T, Semi Y, Sawada H, Utoyama Y, Hosomi Y, Yoshimoto E, Maehata Y, Fukuoka H, Nagata R, Ohyama A (2013) Development of simple sequence repeat markers and construction of a high-density linkage map of Capsicum annuum. Mol Breed 31(4):909-920. doi:10.1007/ s11032-013-9844-x

Tanksley SD, Bernatzky R, Lapitan NL, Prince JP (1988) Conservation of gene repertoire but not gene order in pepper and tomato. Proc Natl Acad Sci USA 85(17):6419-6423
Untergasser A, Cutcutache I, Koressaar T, Ye J, Faircloth BC, Remm M, Rozen SG (2012) Primer3-new capabilities and interfaces. Nucleic Acids Res 40(15):e115-e115

Van Ooijen J (2006) JoinMap 4. Software for the calculation of genetic linkage maps in experimental populations. Kyazma $\mathrm{BV}$, Wageningen

Vasemagi A, Gross R, Palm D, Paaver T, Primmer C (2010) Discovery and application of insertion-deletion (INDEL) polymorphisms for QTL mapping of early life-history traits in Atlantic salmon. BMC Genomics 11(1):156

Vignal A, Milan D, SanCristobal M, Eggen A (2002) A review on SNP and other types of molecular markers and their use in animal genetics. Genet Sel Evol : GSE 34(3):275-305. doi:10.1051/gse:2002009

Voorrips R (2002) MapChart: software for the graphical presentation of linkage maps and QTLs. J Hered 93(1):77-78

Walsh BM, Hoot SB (2001) Phylogenetic relationships of Capsicum (Solanaceae) using DNA sequences from two noncoding regions: the chloroplast atpB-rbcL spacer region and nuclear waxy introns. Int $\mathbf{J}$ Plant Sci 162(6):1409-1418

Wu F, Eannetta NT, Xu Y, Durrett R, Mazourek M, Jahn MM, Tanksley SD (2009) A COSII genetic map of the pepper genome provides a detailed picture of synteny with tomato and new insights into recent chromosome evolution in the genus Capsicum. Theor Appl Genet 118(7):1279-1293. doi:10.1007/s00122-009-0980-y

Xie W, Feng Q, Yu H, Huang X, Zhao Q, Xing Y, Yu S, Han B, Zhang Q (2010) Parent-independent genotyping for constructing an ultrahigh-density linkage map based on population sequencing. Proc Natl Acad Sci USA 107(23):10578-10583. doi:10.1073/pnas.1005931107

Yi G, Lee JM, Lee S, Choi D, Kim BD (2006) Exploitation of pepper EST-SSRs and an SSR-based linkage map. Theor Appl Genet 114(1):113-130. doi:10.1007/s00122-006-0415-y 